AFRICAN

\title{
China-Malawi relations: an analysis of trade patterns and development impli- cations
}

\author{
by Theodora $\mathrm{C}$. Thindwa* \\ Centre for Security Studies, Mzuzu University \\ Mzuzu, Malawi
}

\begin{abstract}
As China is emerging as a force to reckon with in the 21 st century it has formed economic and political partnerships with a number of countries especially in Africa, including Malawi. There are contending views on China's role in Africa with some viewing it as a neo-colonial power and others as Africa's development partner.

This paper investigates how China-Malawi relationship has contributed to economic development in Malawi. This limits the scope of the study to Chinese Government investments directly dealing with the Malawi Government. The article analyses China-Malawi trade patterns, the number of jobs created by Chinese investments and other contributions by China.

Exploratory research design, aspects of descriptive research and mixed methods of analysis is employed to uncover the nature of China-Malawi relations between 2007 and 2012. Using secondary data sources and interviews with principal trade officers, the study found both positive and negative trends. The level of Malawian exports to China is low compared to Chinese exports to Malawi. This entails trade losses for Malawi which in turn has implications for development and also for the society that
\end{abstract}

*Theodora C. Thindwa is a Staff Associate at the Centre for Security Studies at Mzuzu University in Malawi. 
AFRICAN

EAST-ASIAN

AFFAIRS

Malawi is evolving into. Results also suggest that trade gains and losses are affected by the fact that China and Malawi are at different levels of economic development.

Time series analysis shows considerable amount of China's investments to Malawi creating some level of employment for Malawians. Bivariate regression analysis also reveals no relationship between investment levels and employment created. This suggests the importation of Chinese labour into Malawi which leads to economic losses for the Malawian workforce. China is also found to play a positive role in other areas such as: health, education, agriculture and low cost infrastructure.

Overall China has a modest impact on Malawi. China comes out as both a neocolonialist in some areas and as a development actor in other areas. The study suggests various options that could boast Malawi trade and development gains such as addressing standards, supply and demand constraints and also aligning Malawi's educational system to its current trade and development needs.

\section{Introduction}

From the year 2000 African countries had begun to show faster growth rates due to the global shifts in wealth and rise of emerging economic partners namely: South Korea, India, China and Turkey, with China being the most dominant partner [African Development Bank (AfDB); African economic outlook report, 2011; Schiere, Ndikumana and Walkenhorst, 2011].

Trade has been increasing between Africa and emerging partners and stood at US\$ 673.4 billion already in 2011 (AfDB African economic outlook report, 2011). Africa was able to withstand the global financial crisis better than many other world regions, due to an increasing demand of Africa's raw materials that fetched high prices.

From 2005, Africa's per capita income rose faster than that of higher income 


\section{AFRICAN \\ EAST-ASIAN \\ AFFAIRS

countries for the first time since the 1970s. However, poverty, inequalities and lack of inclusive growth remain as some of the challenges for African countries.

Another issue is the influence emerging partners have on the domestic affairs of African countries. The 2011 African Economic Outlook report with the theme "Africa and its emerging Partners" points out that there is no proof that emerging partners are negatively affecting governance, debt sustainability and industrialisation. On the contrary, Oyejide, Bankole and Adewuyi (2009: 486) are of the view that there are both trade related gains and losses from Africa's relationship with its emerging partners. The impact of the gains and losses vary in terms of availability of natural resources, external environment, inherent institutions and policy choices.

Africa's relationship with emerging partners has had an effect on wages, interest rates, manufactured goods, price of commodities and investment. This paper sets out to answer three questions:

1. Has the China-Malawi trade relationship benefited both parties?

Figure 1: Africa's emerging partners and their percentage share of Trade, 2011

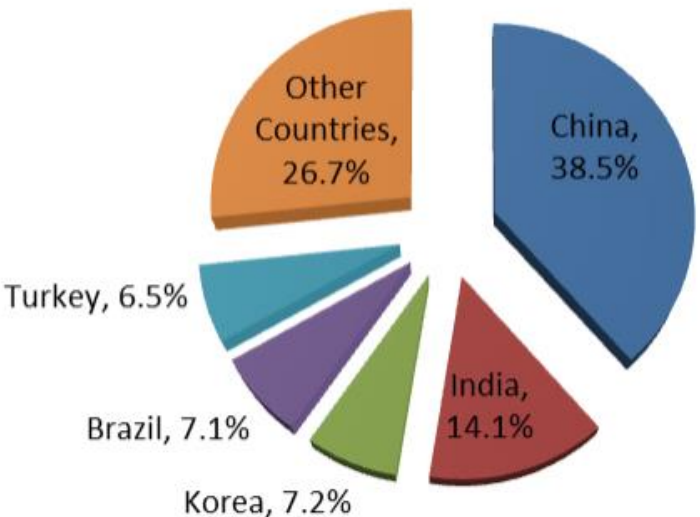

Source: OECD Development Centre calculations based on Comtrade in African Development Bank (AfDB: 2011: 104) 
AFRICAN

EAST-ASIAN

AFFAIRS

2. In what ways has China contributed to employment creation for Malawi?

3. What are the significant strides of development from the China-Malawi relations?

\section{Research methodology and background literature}

\section{China-Malawi literature}

Giovannetti and Sanfilippo (2009) in a study Do Chinese Exports Crowd out African goods? An econometric analysis by country and sector investigate impact of China's trade on Africa via trade channel. Results show that overall trade balance for Malawi is negative and therefore Malawi together with Kenya and Zimbabwe are classified as losing from the trade. A competition analysis of China's relation to Malawi in comparison to Mozambique and Zambia depicted the following results. The level of threat that china presents to Malawi was measured at 64 per cent in comparison to 73.4 per cent and 82 per cent for Mozambique and Zambia respectively

Similarly, Villoria, Hertel and Nin-pratt (2009) explore the link between China's growth and the agriculture exports of sub-Saharan southern Africa countries namely Malawi, Tanzania, Zambia and Mozambique. Study reveals that when China reduces its import expenditure of agriculture goods there is up to a 3.58 per cent reduction in agriculture exports of Malawi and Mozambique. This study reveals an important aspect since agriculture comprises 80 per cent of Malawian exports. Furthermore, agriculture is one of the areas highlighted in China-Malawi trade talks ( Chinese Embassy in Malawi, 2011).

Chinguwo in Baah and Jaunch (2009) examines the impacts of Chinese investment in Malawi prior to the time Malawi switched diplomatic relations from Taiwan to Mainland China. 19 Chinese firms are used as case studies. Results show that a number of Chinese investors paid less attention to their workers welfare. For example, workers would be considered absent when sick and no provision of protective working gear were made. The study does not show how Chinese investment 


\section{AFRICAN \\ EAST-ASIAN \\ AFFAIRS

and labour are linked with other areas of the economy

\section{Analytical Framework}

Since this paper looks at multi-dimensional issues it adopts Kaplinsky, McCormick and Morris (2007)'s synthetic framework for assessing impact of China on Sub Saharan Africa to guide the analysis. Trade flows, Foreign Direct Investment (FDI) flows and aid flows are identified as the three main avenues through which China affects countries in sub-Saharan Africa (table 3). However, this does not mean that these are the only channels, since other channels of influence may arise in other countries depending on contextual factors.

The synthetic framework enables analysis of both complementary and competitive aspects of China-Africa relations on some specific dimensions. This helps in assessing the overall impact.

\section{Background of China-Africa relations}

China-Africa relations have been evolving with China taking the leading role in the direction of the relationship for both economic and political reasons since 1955.

The 1955 Bandung Conference is a precursor to the current relations as Chinese premier Zhou Enlai encouraged solidarity in the fight for self-government and economic self-reliance (Amphiah and Naidu, 2008; Obiorah, 2007 and Karumbidza, 2007). From that time China was actively involved in supporting liberation struggles by providing arms and ideological support especially in socialist African countries such as Tanzania, Zambia and Zimbabwe. China also built the TAZARA railway connecting Tanzania and Zambia. Its first aid program was launched in 1956 in Egypt (Ndulo in Amphiah and Naidu, 2008). High level exchange visits were and are still an important feature of the China Africa relations. From 1976 to 1999 China-Africa relations was based on practical aspects of the Chinese economy which was directed by China's "outward looking strategy" in which china sought to line up its economy with the global economy (Rutaihwa, and Mkawa, 
AFFAIRS

Table 1: A synthetic framework to assess impact of China on Africa

\begin{tabular}{|c|c|c|c|}
\hline & & Direct & Indirect \\
\hline \multirow[t]{2}{*}{ Trade } & Complementary & $\begin{array}{l}\text { Inputs for industries } \\
\text { Cheap consumption of goods }\end{array}$ & $\begin{array}{l}\text { Higher global prices for } \\
\text { Sub-Saharan exports }\end{array}$ \\
\hline & Competitive & $\begin{array}{l}\text { Displacement of existing and } \\
\text { potentiallocal producers by cheap } \\
\text { Chinese products }\end{array}$ & $\begin{array}{l}\text { Competition in extemal } \\
\text { markets-failing prices and } \\
\text { falling market shares }\end{array}$ \\
\hline \multirow{3}{*}{$\begin{array}{l}\text { Production } \\
\text { and FDI }\end{array}$} & & Direct & Indirect \\
\hline & Complementary & $\begin{array}{l}\text { Chinese FDI in sub-Saharan } \\
\text { Africa particularly in fragile states } \\
\text { Cheap and appropriate capital } \\
\text { goods, Technology transfer } \\
\text { Integration in global trade chains } \\
\text { particularly in clothing } \\
\text { Low-cost infrastructure }\end{array}$ & \\
\hline & Competitive & $\begin{array}{l}\text { Displacement of existing and } \\
\text { Potential local producers } \\
\text { Less spin-off to local economy } \\
\text { than other foreign contactors } \\
\text { Use of scarce resources }\end{array}$ & $\begin{array}{l}\text { Competition for global } \\
\text { FDI and production } \\
\text { platforms. } \\
\text { Disinvestment and } \\
\text { relocation by other foreign } \\
\text { investors (eg. clothing and } \\
\text { fumiture) }\end{array}$ \\
\hline \multirow[t]{2}{*}{ Aid } & Complementary & $\begin{array}{l}\text { Grants and concessional finance } \\
\text { Technical assistance } \\
\text { Training }\end{array}$ & \\
\hline & Competitive & & $\begin{array}{l}\text { Chinese aid to Latin } \\
\text { America creates } \\
\text { productive capacity which } \\
\text { competes with sub- } \\
\text { Saharan Africa producers } \\
\text { and lowers export prices }\end{array}$ \\
\hline
\end{tabular}

Source: Kaplinsky, McCormick and Morris (2007)

2011). It is worth noting that Wang (2009) in Borovska (2011) identifies three stages of China's engagement with Africa namely the political stage, idle stage and commercial stage. This is shown in the table below. 


\begin{tabular}{|c|} 
AFRICAN \\
EAST-ASIAN \\
AFFAIRS \\
\hline THE CHINA MONITOR \\
\hline
\end{tabular}

\begin{tabular}{|c|c|c|}
\hline $\begin{array}{l}\text { Political stage (1955- } \\
\text { 1970s) }\end{array}$ & Idle stage (1980-1990) & Commercial stage (1990- 2000s) \\
\hline $\begin{array}{l}\text {-Mainly political ties } \\
\text {-Infrastructure and } \\
\text { medical aid } \\
\text {-Determination to find } \\
\text { support for the third world }\end{array}$ & $\begin{array}{l}\text {-China focusing on domestic } \\
\text { restructuring to participate in the world } \\
\text { economy to a larger extent. } \\
\text {-Developing a strong position at the } \\
\text { global level. } \\
\text {-Restructuring China's domestic } \\
\text { economy. } \\
\text {-Spreading political power less } \\
\text { important in this phase. }\end{array}$ & $\begin{array}{l}\text {-China establishes its position as an } \\
\text { emerging economic power. } \\
\text {-Booming economy increases the need for } \\
\text { more natural resources and raw materials } \\
\text { such as oil, steel and Cotton found in Africa } \\
\text { involving:- } \\
\text { State Owned Enterprises(SOE) backed by } \\
\text { state to state deals } \\
\text { State owned at provincial level } \\
\text {-Private owned Chinese firms and small and } \\
\text { medium Chinese firms forced out of China } \\
\text { by intense competition. These see their } \\
\text { investments in low income economies as } \\
\text { opportunities to learn about foreign } \\
\text { investment in less demanding global } \\
\text { markets. } \\
\text {-Chinese commercial ties with Africa } \\
\text { cemented at the Forum on China-Africa } \\
\text { Cooperation (FOCAC). } \\
\text {-Growing investments and financial flows } \\
\text { to numerous sectors and industries }\end{array}$ \\
\hline
\end{tabular}

Source: Boroyska(2011) and additions from Kaplinsky (2012)

While China has been evolving the way in which it deals with Africa nothing much is said about how Africa has evolved. This seems to suggest the position of Africa as being that of a passive actor in the relationship. This may in turn affect how the benefits of the relations are shared between Africa and China.

\section{Brief outline of Malawi's economy}

Malawi attained its independence from the United Kingdom on the 6 July 1964. Malawi is a land locked country with a population of about 15 million. Malawi is a country with diverse natural resources: land, water, forestry and minerals most of which are still underdeveloped. Since independence, the structure of Malawi's economy has been erratic. Growth rates higher in 1970, lower in 80s and 1990s and 
AFRICAN

EAST-ASIAN

AFFAIRS

higher again after 2000(Mbekeani, 2004:215) In 2009 gross domestic product (GDP) growth expanded by 7.6 per cent driven by agriculture, a newly commissioned uranium mine and information and technology.

Malawi economic structure is agricultural dependent with tobacco, tea, and sugar as its most important export crops (UNDP, 2011: 32). As of February 2013, Agriculture represents 29.6 per cent of GDP; the service sector contributes about 53.5 per cent (estimate) up from 35 per cent in 2005 and industry contributes 16.9 per cent. Nearly 90 per cent of the population is engaged in subsistence farming. Recent explorations by foreign mining companies have found deposits of rare earth, uranium, niobium and bauxite (Mshali, 2009; World Bank, 2009).

In 2012 the real GDP growth slowed down due to the contraction of the agriculture and manufacturing sectors. Slow growth is also attributed to a shortage of foreign currency, lack of proper working institutions such as government and other private institutions, drought and weak policies. Poverty, rising inequality and vulnerability to external shocks remain challenges impeding on Malawi's progress (IMF World Economic Outlook, 2012; African Economic Outlook, 2012).

The Malawi government launched its development and growth strategy, the Malawi Growth and Development Strategy MGDS II (2011-2016) in 2012 with the objective of wealth creation and poverty reduction. It identifies six thematic areas namely sustainable economic growth, social development, social support, infrastructure development, improved governance and cross cutting issues such as capacity development and gender (Malawi Government 2012. The paper will also briefly look at how China has contributed to some of these areas and what it means for the development of Malawi.

\section{China-Malawi diplomatic relations}

Malawi first recognised the Republic of Taiwan as representing China in 1967 under the leadership of late Dr. Kamuzu Banda.

However, Malawi established diplomatic ties with China on the 28 December 2007 


\section{AFRICAN \\ EAST-ASIAN \\ AFFAIRS \\ THE CHINA MONITOR}

under the "One China policy" thereby severing its 41 year old ties with Taiwan. (Chinguwo in Baah and Jaunch (2009:273). According to the One China Policy the People's Republic of China (PRC) is the sole representative of China of which Taiwan is a part. This entails that under the "One China Policy" a country must sever its ties with Taiwan if it is to establish diplomatic ties with China (Chiang, 2004)

The Malawi government justified the new ties on the basis that "China has become an economic giant that a developing country like Malawi cannot ignore" (ibid: 273). The Chinese ambassador to Malawi Lin Songtian justified China's presence on the basis of being able to contribute towards efforts to achieve national development and improve living standards of Malawian people through job creation (Chinese Embassy in Malawi, 2011).

On 13 May 2008 China signed a Memorandum of Understanding (MOU) with Malawi with the aim of enhancing investments and trade ties. Four priority areas are identified in the MOU namely infrastructure, agriculture, education and public health as areas of co-operation (Chinese Embassy in Malawi , 2011)

The Malawi China relation reached its climax in 2011 when all the major donors pulled out due to the country's poor governance and the erosion of democratic principles (Thomas Reuters Foundation, 2011).

Under the circumstances, China was the only partner left after the withdraw of Malawi's traditional development partners. The 2011 African Development Bank "Africa Economic Outlook report" stated that "China is the single most important emerging partner for Malawi” providing grants and concessional loans for various infrastructure projects (AfDB, 2011:13).

\section{China-Malawi bi-lateral relations and development assistance and investment in Malawi}

Trading with China with a population of about 1.35 billion could be advantageous for Malawi as China provides markets for Malawi's agricultural products (MITC, 2012). On the other hand China exports a wide range of manufactured goods and processed products to Malawi (UN COMTRADE in International Trade Centre, 
AFFAIRS

2012).

Most of the studies on the impact of China-Africa trade relations show that there is a trade imbalance between China and Africa, with more benefits accruing to China, except for Zambia.

Ancharaz, Vinaye and Baboo,(2010); Ruitaihwa, Mkwawa and Ramadhan (2011); Adewuyi et al (2010) all find that China's exports to Africa has been increasing while African exports to China have been steadily increasing but remain low compared to the volume of China's exports to Africa. For example, in Nigeria Adewuyi et al (2010) find that in 2005 Nigerian exports to China totalled US\$ 1.2 million while Nigerian imports from China totalled US\$ 13 million. Similarly, Ruitaihwa, Mkwawa and Ramadhan (2011) finds that in 2010 Tanzanian exports to China stood at US\$ 643540 while imports from China stood at US\$ 866040 . But they do not interrogate further what the trade inequality between China and Africa could mean for the economic development issues of countries involved. Some of these studies have not questioned how Chinese investments have contributed to employment of the countries studied and whether they are in pro poor areas. Except for studies such as that of Ruitaihwa, Mkwawa and Ramadhan (2011) which looks at sector distribution of Chinese employment in Tanzania. That study finds that Chinese investments are capital intensive but have created jobs for Tanzania mainly in manufacturing sector followed by construction and tourism sectors. Consequently, there has been a positive contribution to economic growth and reduction of income poverty. Nevertheless, the Tanzania study does not show how many Chinese workers are employed in these sectors. This could be due to the difficulty in finding reliable data from the Chinese side on the total number of jobs created for Chinese workers in Chinese investments.

In a nutshell, trade between China and Malawi has been increasing over the years. China's current ambassador to Malawi, Pan Hejun pointed out that the Malawi trade volume with China was US\$ 100 million dollars in 2011 representing a 400 per cent jump over 2010. Furthermore, Chinese foreign direct investment (FDI) to Malawi jumped from "US\$ 0.96 million in 2006 to US\$ 11.25 million by 2009 with over 55 


\section{AFRICAN \\ EAST-ASIAN \\ AFFAIRS

per cent of investments" in manufacturing sector (African Development Bank, 2011).

China pledged aid amounting to US\$ 270 million dollars for a period of 5 years from 2007 to 2012. However, it appears more than US\$ 270 million dollars has been provided. Assistance from China is complementing the traditional donors especially in terms of infrastructure development.

However, some of the projects are funded by Chinese government loans which Malawi government will have to pay back. This in turn raises questions of Malawi increasing its debt burden and its implications for inter-generational debt. On infrastructure projects Chinese companies are the main contractors of the projects. This seems to be the condition that China attached to its assistance to Malawi. These Chinese companies have a significant share of Chinese workers. In some cases construction materials and equipment also comes from China (African Development Bank, Economic Outlook Report, 2011).

As of September 2012, 196 Chinese firms were registered with Malawi Investment and Trade Centre in manufacturing, tourism, services, building and agriculture.

Table 3: Chinese investments by sector as of September 2012

\begin{tabular}{|l|l|}
\hline Sector & Number of companies \\
\hline Manufacturing & 132 \\
\hline Tourism & 15 \\
\hline Services & 37 \\
\hline Agriculture/ farming & 8 \\
\hline Import and Distribution & 1 \\
\hline Building and bore hole drilling & 2 \\
\hline Mining & 1 \\
\hline Total & $\mathbf{1 9 6}$ \\
\hline
\end{tabular}

Source: $M I T C, 2012$ 
AFRICAN

EAST-ASIAN

AFFAIRS

\section{Heterogeneous nature of Chinese presence in Malawi}

Kaplinsky et al (2007) and McNamee et al (2012) argue that China's presence in Africa reveals different layers: individual Chinese traders, private Chinese investors and also state backed investors all trying to make the most of opportunities in Africa.

There has been a mushrooming of Chinese traders in district trading centres in Malawi as either shop owners or general merchandise traders. This has created tensions with local traders as local businesses are no longer profitable since Chinese traders offer cheaper prices. In response to this, the government of Malawi introduced the Business Licensing Act of 2012, which prescribes the types of investments foreigners can engage in the rural areas of Malawi. Foreigners will be allowed to operate only in the main cities and have to apply for permits with a deposit of US\$250,000 as initial capital (World Bank Doing Business, 2012; Ngozo, 2012). Chinese ambassador to Malawi pointed out that

It is up to the Malawi government to thoroughly screen the Chinese nationals willing to invest in the country. These are small vendors and why should the Malawi government allow them to do business? They are capitalising on government's failure to screen foreign traders."

Chinese Embassy in Malawi supported the new law. It seems the Chinese traders are not part of China's policy for Malawi as they migrated to Malawi for their own individual business gains.

\section{Analysing the China-Malawi economic relationship}

The different economic sizes of the two countries and overall growth have an impact on the relations of the two countries. While both China and Malawi are developing countries, they are not equals. Malawi's economy is largely agriculture based as explained in the introduction while China has grown to become an industry based economy with a strong manufacturing base. China is bigger geographically, population wise, as well as economically. As a result, allocation of resources to various 


\section{AFRICAN \\ EAST-ASIAN \\ AFFAIRS

areas of the economy is also different depending on the peculiar problems faced by each country. Each country could gain or lose from the relationship depending on the capacity of the economy.

In general, exports from Malawi to China have been increasing. But the percentage share of Malawi's total trade with China has been fluctuating from 13 per cent in 2007 down to 8 per cent in 2008 and further down to 7 per cent in 2009 . This decline could be due to the global financial crisis of 2008/2009.

There is a trade imbalance which is in favour of China. This is because Malawi exports primary unprocessed products, which are subject to price fluctuations at the global level. On the other hand, China exports manufactured value added goods, which fetch high prices due to the value addition.

On the Chinese side, imports from China to Malawi are mostly value added products. The imports to Malawi from China have also been increasing. In terms of percentage share, China has a higher percentage share of trade with the highest in 2009 at 93 per cent, compared to exports to China at 7 per cent. In 2010, import percentage share fell to 86 per cent, 80 per cent in 2011 and increased by 2 per cent to 82 per cent in 2012. China's larger share of the imports to Malawi is due to more penetration of its products which are diversified and in larger quantities, taking into consideration the large size of the Chinese economy.

\section{Development Implications of the trade imbalance for Malawi}

Chinguwo in Baah and Jauch (2009) and the 2011 African Development Bank Economic outlook report show both advantages of the China-Malawi trade patterns. One of the advantages is that they provide increased employment and economic activities in Malawi. Chinese goods are also relatively cheaper and therefore may increase the consumer welfare especially for the poor who are able to derive benefits from a cheaper version of a product.

However, the benefits from trade are not as significant for Malawi since the balance of trade favours China over Malawi. This state of affairs has implications 
AFRICAN

EAST-ASIAN

AFFAIRS

Table 4: Value and Percentage share of China-Malawi trade (2007-2012)

\begin{tabular}{|c|c|c|c|}
\hline 2007 & Value in USS & Quantity & $\begin{array}{l}\text { Percentage } \\
\text { share of } \\
\text { trade }\end{array}$ \\
\hline $\begin{array}{l}\text { Malawi's total exports to } \\
\text { China }\end{array}$ & $6,414.08$ & $\mathrm{~N} / \mathrm{A}$ & $13 \%$ \\
\hline $\begin{array}{l}\text { Total imports from China to } \\
\text { Malawi }\end{array}$ & $41,203.95$ & $\mathrm{~N} / \mathrm{A}$ & $87 \%$ \\
\hline Trade Balance & $-34,789.87$ & & \\
\hline 2008 & & & \\
\hline $\begin{array}{l}\text { Malawi's total exports to } \\
\text { China }\end{array}$ & $7,157,598.38$ & $3,087,556$ & $8 \%$ \\
\hline $\begin{array}{l}\text { Total imports from China to } \\
\text { Malawi }\end{array}$ & $78,228,345.87$ & $82,488,613$ & $92 \%$ \\
\hline Trade Balance & $-71,070,747.49$ & - $79,401,057$ & \\
\hline 2009 & & & \\
\hline $\begin{array}{l}\text { Malawi's total exports to } \\
\text { China }\end{array}$ & $8,685,121.62$ & $4,509,210$ & $7 \%$ \\
\hline $\begin{array}{l}\text { Total imports from China to } \\
\text { Malawi }\end{array}$ & $109,019,230.20$ & $136,727,275$ & $93 \%$ \\
\hline $\begin{array}{l}\text { Trade Balance } \\
2010\end{array}$ & $-100,334,108.58$ & $-132,218,065$ & \\
\hline $\begin{array}{l}\text { Malawi's total exports to } \\
\text { China }\end{array}$ & $33,000,012.22$ & $25,488,173$ & $14 \%$ \\
\hline $\begin{array}{l}\text { Total imports from China to } \\
\text { Malawi }\end{array}$ & $197,115,246.20$ & $308,992,679$ & $86 \%$ \\
\hline Trade Balance & $164,115,233.98$ & $-\quad 283,504,506$ & \\
\hline 2011 & & & \\
\hline $\begin{array}{l}\text { Malawi's total exports to } \\
\text { China }\end{array}$ & $59,680,972.59$ & $57,496,818$ & $20 \%$ \\
\hline $\begin{array}{l}\text { Total imports from China to } \\
\text { Malawi }\end{array}$ & $233,477,434.77$ & $224,932,822$ & $80 \%$ \\
\hline Trade Balance & $-173,796,462.18$ & - $\quad 167,436,004$ & \\
\hline 2012 & & & \\
\hline $\begin{array}{l}\text { Malawi's total exports to } \\
\text { China }\end{array}$ & $237,734.33$ & - & $18 \%$ \\
\hline $\begin{array}{l}\text { Total imports from China to } \\
\text { Malawi }\end{array}$ & $1,066,275.94$ & - & $82 \%$ \\
\hline Trade Balance & $828,541.61$ & & \\
\hline
\end{tabular}

Source: Malawi Ministy of Trade, and author's own calculation 


\begin{tabular}{|c|} 
AFRICAN \\
EAST-ASIAN \\
AFFAIRS \\
\hline THE CHINA MONITOR \\
\hline
\end{tabular}

Table 5: Disaggregation of some of Malawi Exports to China

\begin{tabular}{|l|l|l|}
\hline COMMODITY & VALUE IN US\$ & QUANTITY \\
\hline $\begin{array}{l}\text { Raw Sugar } \\
(2008,2011)\end{array}$ & $344,970.31$ & 1,180 kilos \\
\hline $\begin{array}{l}\text { Black Tea: fermented and partly fermented } \\
(2009,2010,2011)\end{array}$ & $540,394.74$ & 206,274 kilos \\
\hline $\begin{array}{l}\text { Coffee: both roasted and not roasted } \\
(2009,2010)\end{array}$ & $44,016.76$ & 22,300 kilos \\
\hline $\begin{array}{l}\text { Cotton: carded combed and Cotton waste } \\
(2008,2009,2010 \text { and } 2011)\end{array}$ & $2,714,314.99$ & $3,898,719$ kilos \\
\hline $\begin{array}{l}\text { Tobacco: stemmed, stripped and refuse } \\
(2008,2009,2010 \text { and 2011) }\end{array}$ & $23,798,331.53$ & $5,952,402$ kilos \\
\hline TOTAL & $\mathbf{2 7 , 4 4 2 , 0 2 8 . 3 3}$ & $\mathbf{1 0 , 0 8 0 , 8 7 5}$ \\
\hline
\end{tabular}

Source: International Trade Centre COMTRADE Database, 2012 and

Malawi Ministry of Trade and Industry

Table 6: Disaggregation of some of the Chinese imports to Malawi

\begin{tabular}{|l|l|l|}
\hline COMMODITY & VALUE IN US\$ & QUANTITY \\
\hline $\begin{array}{l}\text { Quick lime and hydraulic lime } \\
(2008,2009,2010,2011)\end{array}$ & $5,063.05$ & $18,015 \mathrm{kilos}$ \\
\hline $\begin{array}{l}\text { Gases and lubricating oil, rare gases, petroleum oil } \\
\text { and oils obtained from bituminous mineral, distilled } \\
\text { and other fuels } \\
(2010,2011)\end{array}$ & $86,208.27$ & 580 litres \\
35,492 kilos \\
\hline $\begin{array}{l}\text { Cigarettes and related } \\
(2008,2009,2011)\end{array}$ & $14,532.65$ & $12,340 \mathrm{kilos}$ \\
\hline $\begin{array}{l}\text { Fertilizers, animal and veg fertilizer } \\
(2008,2009,2010)\end{array}$ & $41,959,509.91$ & $44,322,998 \mathrm{kilos}$ \\
\hline $\begin{array}{l}\text { Paving blocks of glass, for building, construction } \\
\text { purposes, base metal for building, prefabricated } \\
\text { building and its structural components }\end{array}$ & $473,148.85$ & 587,423 \\
\hline TOTAL & $\mathbf{4 2 , 5 3 8 , 4 6 2 . 7 3}$ & $\mathbf{4 4 , 9 7 6 , 2 6 8}$ \\
\hline
\end{tabular}

Source: International Trade Centre COMTRADE Database, 2012 and Malawi Ministry of Industry and Trade and Tralac (Trade Law Centre). 
AFRICAN

EAST-ASIAN

AFFAIRS

for development and also for the society Malawi is evolving into. Firstly, it implies a replication of the dependency relationship of colonialism which left colonies exploited and poor, thereby leading to exploitation and underdevelopment. The situation could lead to imported inflation and inflationary pressures of unemployment (in primary sectors exporting to China due to low income benefits).

In the long run the trade might inhibit growth of emerging local industries with negative consequences for creation of jobs if Malawi continues to import consumer goods that could be produces locally. Consequently, Malawian society is evolving into a society dependent on manufactured goods from China, which is not able to develop its entrepreneurship and social innovation skills that could develop Malawi. Therefore in the long term, the trade is unsustainable. However, it is worth noting that Malawi has benefited in other non-trade avenues, which will be looked at in detail later.

\section{Reasons for low export penetration of Malawian exports to China}

Results of Skype interviews followed by email conversation on $7^{\text {th }}$ February,2013 with three principal officials from the Malawi's Ministry of Industry and Trade reveal that there are supply constraints, demand constraints and standards constraints for the low export penetration of Malawi's exports to China. On the supply side, the reasons for low export penetration are quality of products and lack of value addition as Malawi exports raw products which fetch low prices on the international market. Low productivity has also affected the supply side in that the final output is either of insufficient quantity or of poor quality. On the demand side one of the trade officers pointed out that:

"Up to now people have no knowledge that their products can be exported and even fewer understand the knowhow." (Banda, 2013)

In terms of standards, poor quality of support infrastructure such as water, electricity and transport, has a negative effect on export penetration. Another officer also highlighted the poor implementation of specific Acts. For instance, the Malawi Bureau of Standards Act was developed with the sole purpose of ensuring that products meet the standards and quality in Malawi. 


\section{AFRICAN \\ EAST-ASIAN \\ AFFAIRS

"despite having the Act the challenges are lack of metrological equipment which are meant to test standards of specific imports such as Chinese imports to Malawi."

In addition, the high cost of production makes most of the Malawian products uncompetitive on the international market. Standards constraints that contribute to low export penetration are the lack of accredited bodies for conformity assessment. This delays exports and also prohibits exports. Lastly, most companies in Malawi do not operate under economies of scale, thereby making access to larger markets difficult and also making their products less competitive.

China's Impact on the manufacturing sector: the case of the leather shoe industry)

One of the Principal Trade Officer's in the Ministry of Industry and Trade (2013) also shared the preliminary results of an on-going study on China's effect on manufacturing sector. Preliminary results point to the negative impacts of China on the leather industry in Malawi.

One result is that there is an inverse relationship between shoe production by local shoe companies and the influx of Chinese shoes in Malawi.

"Small and Medium Enterprises (SMEs) in Malawi make less than 1000 pairs of shoes annually compared to 100,000 pairs it used to make 20 years ago. The shoe manufacturing sector used to employ more than 300 people about 20 years ago, and now employs about 50 people. This is linked to the high demand of Chinese shoes and lower demand for locally made shoes" (Malawian Ministry of Industry and Trade, 2013).

Results also reveal that the presence of Chinese investors in the sector has not really helped to improve the situation. This is because the Chinese investors "externalise the raw hides and skins for their companies in China" (Malawian Ministry of Industry and Trade, 2013).

Furthermore, there has been limited technology transferred in some sectors in which 
AFRICAN

EAST-ASIAN

AFFAIRS

Chinese have ventures. Lastly, Chinese investment in Malawi is characterised by labour importation from China in some sectors such as construction.

\section{What Malawi spends in terms of GDP percentage to import from China}

Malawi's GDP in expenditure terms has been mainly used to import goods and services from China. The ratio has increased from 1.23 to 1.42 from 2010 to 2012, providing concrete evidence of Malawi's increased import spending from China. This entails an increasing dependency on Chinese imports which in turn increase the negative balance of trade representing losses for Malawi.

\section{Chinese contribution in job creation for Malawians.}

In order to find out how China's investment has contributed to employment creation, two types of analysis were computed. Firstly, time series analysis to show the evolution of Chinese investments from 2005 to 2008 and secondly, bivariate regression was computed to establish whether there is a correlation between investment and employment created.

An interesting trend indicates the largest inflow of Chinese investment, mainly in

\section{Table 7: Ratio of China-Malawi trade as a percentage of GDP}

\begin{tabular}{|c|c|c|c|c|}
\hline & Exports & Imports & GDP (PPP) & China's ratio to GDP \\
\hline 2010 & $33,214,000.00$ & $198,391,000.00$ & $13,400,000,000.00$ & 1.23 \\
\hline 2011 & $57,566,000.00$ & $224,610,000.00$ & $13,980,000,000.00$ & 1.19 \\
\hline 2012 & $59,222,000.00$ & $265,620,000.00$ & $14,580,000,000.00$ & 1.42 \\
\hline
\end{tabular}

Source: Ministry of Industry and Trade data

manufacturing. This is in various areas such as shoes, slippers and agro-processing, followed by investments in tourism and services such as photo processing, catering, advertising and Chinese medicine. This implies that manufacturing ventures bring in the highest investment in all the years.

Chinese investments are quite diverse in Malawi, ranging from manufacturing in 


\section{AFRICAN \\ EAST-ASIAN \\ AFFAIRS

various sectors, natural resource extraction, telecommunication, agriculture and services. China has created a total of 13796 jobs from 2005 to 2012 which is a significant number. Nevertheless, considering the total investment by China, the total employment generated has been very low.

In 2008, actual number of jobs created by Chinese investment was 2173, compared to the expected number of jobs at 311021 .

Figure 2: Cross sectional graph on Chinese investments (2005-2008)

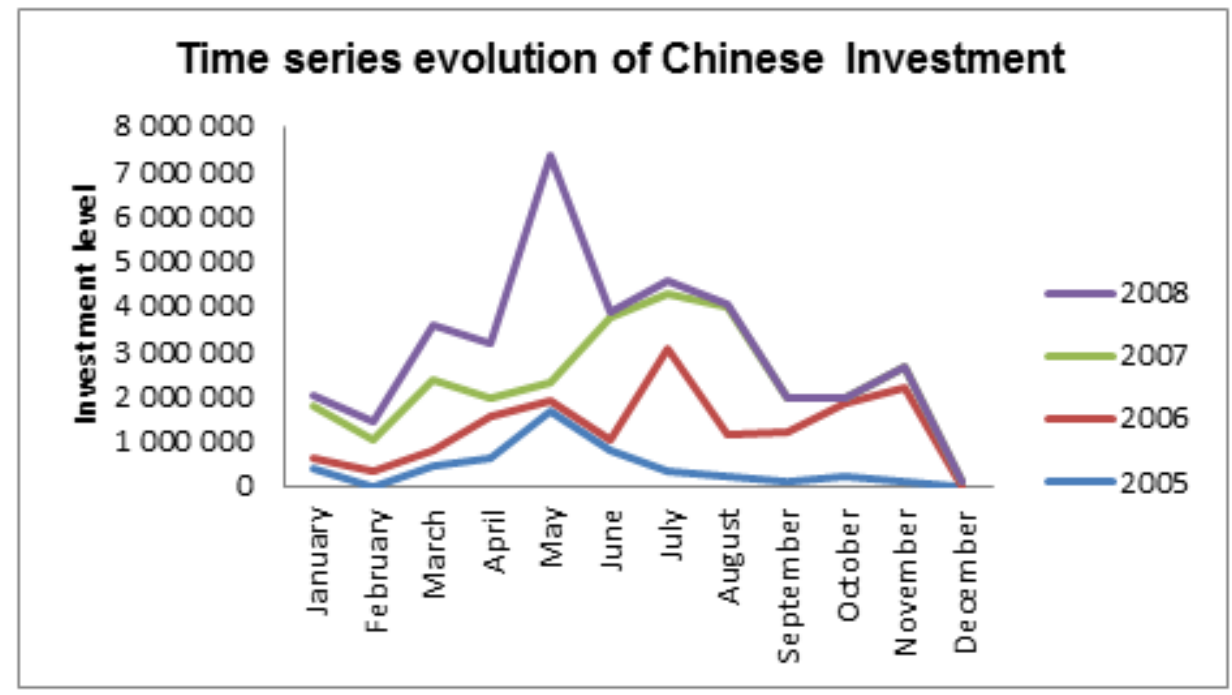

Source: Author's own calculations

An interesting observation is that the largest numbers of jobs were created in 2011. This is because the registered firms each pledged to employ a significant number of Malawians. In the manufacturing sector (plastic plates) 3202 jobs were created, in the tourism sector 2000 jobs were created, Agriculture (cashew) created 500 jobs, 
AFRICAN

EAST-ASIAN

AFFAIRS

manufacturing (bicycles, electronics) 500 jobs and food processing created 600 jobs. However, it is not clear if these figures are a true reflection of the total number of people employed by the Chinese firms. The Malawi Investment and Trade Centre reports that it is difficult to follow up the Chinese firms as most either change location or cannot be traced, indeed a very worrying trend.

Bivariate regression analysis was also computed to establish whether there is a correlation between Chinese investment and the number of jobs created (for 2005 to 2008). It is worth noting that correlation does not imply a causal relationship between the two variables: Chinese investment and jobs created. The value of the correlation is represented by the Pearson's correlation coefficient, $\mathrm{R}$, ranged from 0 to 1 . The stronger the relationship, the closer the $\mathrm{R}$ will be to 1 and the weaker the relationship the closer to 0 .

Table 8: Total amount of Chinese investments and number of jobs created over the years

\begin{tabular}{|l|l|l|l|}
\hline Year & $\begin{array}{l}\text { Total Chinese } \\
\text { investments in } \\
\text { USs }\end{array}$ & $\begin{array}{l}\text { Total jobs } \\
\text { created } \\
\text { Chinese } \\
\text { investment }\end{array}$ & $\begin{array}{l}\text { Expected number of jobs calculated } \\
\text { using 2008/2010 urban minimum wage }\end{array}$ \\
\hline $\mathbf{2 0 0 5}$ & $4,899,000$ & 1116 & \\
\hline $\mathbf{2 0 0 6}$ & $10,742,400$ & 1072 & \\
\hline $\mathbf{2 0 0 7}$ & $12,383,000$ & 2144 & \\
\hline $\mathbf{2 0 0 8}$ & $8,584,189$ & 2173 & 311021 \\
\hline $\mathbf{2 0 0 9}$ & $29,188,036$ & 425 & 105754 \\
\hline $\mathbf{2 0 1 0}$ & 763,000 & 393 & 27644 \\
\hline $\mathbf{2 0 1 1}$ & $56,874,575$ & 7290 & 20607 \\
\hline $\mathbf{2 0 1 2}$ & $21,420,000$ & 299 & 77609 \\
\hline
\end{tabular}

Source: computed from data provided by Malawi Investment and Trade Centre, 2012

Correlation values indicate that there is a relatively weak relationship between investment levels and employment for 2005 and 2006. In 2005 there was a relatively weak positive relationship with $\mathrm{R}$ value of 0.186 and also positive similar relationship was observed in 2006 with an $\mathrm{R}$ value of 0.246 . 


\section{AFRICAN \\ EAST-ASIAN \\ AFFAIRS

From 2007 and 2008, there is a more positive relationship with the 2007 correlation value of 0.514 . In 2008, the correlation is much stronger with an $R$ value of 0.953 Nevertheless, the correlation is not conclusive but simply reveals a trend that could have been properly followed to 2012 if the data was readily available.

The paper finds that China has contributed to some job creation in Malawi but on a very limited scale as compared to investment size.

\section{China's contribution to infrastructure in Malawi and linkages with Malawi Growth and Development Strategy (MGDS II)}

China has been involved in a number of infrastructure projects funded under both concessional loan arrangements and grants. China has funded and constructed roads (Karonga-Chitipa Road), buildings such as Parliament building, an international convention centre, and a hotel which are contributing positively to infrastructure development. However, the question that needs further clarification is whether the infrastructure developed is in the key productive areas of the economy.

African Development Bank (Malawi office) and government officials argue that China is contributing to some of the key areas set out in the Malawi Growth and Development Strategy (MGDS II). The recent development strategy (MGDS II) is the road map for Malawi to reduce poverty through sustainable economic growth and infrastructure development from 2011 to 2016 (Malawi Government 2012). The six broad thematic areas are further broken down into nine ${ }^{1}$ key areas. For instance, infrastructural development, one of the key areas identified in the MDGS II. China has contributed to this sector in the form of energy, transport (roads) and also to information and communication as will be explained soon.

According to information published on the Chinese Ministry of Foreign Affairs website (2012), on 26 June 2013, Malawi signed a US\$ 667.233 million energy deal with TBEA Chinese Company. The energy compact will facilitate construction of additional power lines and the upgrade electricity transmission lines in Malawi. The deal is to be financed by the China EXIM bank. This will contribute to addressing one of the challenges facing growth in the industry sector in Malawi that of erratic 
AFRICAN

EAST-ASIAN

AFFAIRS

electricity supply. The study also finds that one of the four power lines, the Kasungu line, is expected to be in areas with mining prospects: limestone for cement, niobium and other minerals. It can be argued that China displays its strategic thinking in line with those who argue that China is in Africa to satisfy its resource needs. While electricity generation output for Malawi increases, it will at the same time enable China to extract the natural resources for its own needs. Furthermore, China will be contributing to one of the priority areas of the Malawi government: the mining sector.

Another facet of the energy deal is the coal fired thermal electricity project signed between the Malawi government and China Gezhouba group Company (CGGC). The coal project is expected to produce about 1000 megawatts of electricity and use about 400,000 tonnes of coal annually.

The Malawi government, together with China, should have sought to develop other clean sources of energy, such as the geothermal electricity potential that Malawi already has from its 21 hot springs located across Malawi (Dulanya, 2006).

\section{China's role in Malawi's agriculture sector and prospects role in food security}

In line with one of the areas of the MOU, China has contributed positively to the agriculture sector. One of the criteria of Kaplinsky's analytical framework, China is complementing Malawi's efforts by using its advantage in agriculture. The study finds that one of the key contributions is the China-Malawi cotton project which is a joint investment from China-Africa development fund. The cotton project involves the China Colored Cotton Group and Qingdao Ruichang Cotton Industrial Co Ltd. It is reported that the project benefits 100000 local farming households, and provides a significant contribution to the income levels of farming families as their cotton is exported to China. Consequently, this has a positive impact on income levels of the benefiting cotton farmers (Ministry of Foreign Affairs of the People's Republic of China, 2010)

Another aspect of China's role in agriculture is the deployment of Chinese agriculture experts and technicians through the China/Food and Agriculture Organisation (FAO) SOUTH-SOUTH cooperation. As of April 2013, 18 Chinese experts were 


\begin{tabular}{|c|} 
AFRICAN \\
EAST-ASIAN \\
AFFAIRS \\
\hline THE CHINA MONITOR \\
\hline
\end{tabular}

Table 9: Chinese Government pledge to Malawi and the projects involved

\begin{tabular}{|l|l|l|}
\hline Project & Amount in USS & status \\
\hline *New Parliament Building & 40 million (in grants) & completed \\
\hline *101 Km Karonga Chitipa road & 55 million & $\begin{array}{l}\text { Completed in December } \\
2012\end{array}$ \\
\hline Construction of a 5 star hotel & 90 million (concessionary loan) & completed \\
\hline Cotton investment Project in Balaka & 25 million & $\begin{array}{l}\text { Commenced on 25 th June } \\
2012\end{array}$ \\
\hline 40,000 seater soccer stadium & 65 million (concessionary loan) & $\begin{array}{l}\text { Currently being constructed } \\
\text { in Lilongwe }\end{array}$ \\
\hline $\begin{array}{l}\text { University of Science and Technology } \\
\text { building structures ( recent addition) }\end{array}$ & 80 million & completed \\
\hline $\begin{array}{l}\text { Construction of new Ministry of Defense and } \\
\text { Malawi Defence forces headquarters }\end{array}$ & 4 million dollar & In the pipeline \\
\hline $\begin{array}{l}\text { Fumiture and vehicle for Govemment of } \\
\text { Malawi Ministry of Foreign Affairs (grants } \\
\text { and goods) }\end{array}$ & 300 thousand dollars & completed \\
\hline $\begin{array}{l}\text { Kanyika multi commodity project( China } \\
\text { Development Bank letter of intent to finance } \\
\text { feasibility }\end{array}$ & 220 million dollars & $\begin{array}{l}\text { Expression of letter of intent } \\
\text { (LOI) }\end{array}$ \\
\hline $\begin{array}{l}\text { Building of 1,000 megawatts thermal } \\
\text { electricity plant }\end{array}$ & 500 million dollars & $\begin{array}{l}\text { MOU signed on } 30^{\text {th }} \text { August } \\
\text { 2012 }\end{array}$ \\
\hline
\end{tabular}

Source: Chinese Embassy website in Malawi and media compiled by author

involved in field demonstrations and hands-on training. They were also involved in agronomy; farm mechanisation; agriculture production and marketing; animal husbandry; fisheries and aquaculture and also conservation agriculture, to mention a few. The Chinese experts also contributed to capacity building of farmers and extension workers on modern farming practices. Some of the extension workers also went on a study tour to China.

There are prospects that China can help in boosting Malawi's food security. About 80 per cent of Malawian is dependent on subsistence agriculture and a few are involved in commercial agriculture (FAO, 2003) Agriculture is also a source of food and employment for the informal economy. China can extend its expertise to increase the productive capacity of crops like maize, beans and vegetables which form an important part of the diet for most Malawians. China can also look at agri- 
AFRICAN

EAST-ASIAN

AFFAIRS

business potentials of some crops such as tomatoes and mushroom which can be processed and packed within Malawi for export.

\section{Role of China in Malawi public health sector}

Chinese doctors have been working in various hospitals in Malawi. As of 2011, the Malawi Ministry of Health reports that 17 Chinese doctors were working in Malawi. An additional 9 doctors were working on the China-Malawi visual recovery project (mostly cataract surgery) which mostly affects people in the rural areas of Malawi. Chinese volunteers have also been working across the 28 districts of Malawi. (Malawi Ministry of Health, 2013; Chinese Embassy in Malawi, 2010 )

\section{China's contribution to Malawi's education sector}

Similar to some of the studies, China has been providing study scholarships for Malawians to study at Chinese Universities in various disciplines. The scholarships have been at bachelors, masters and also doctor of philosophy (PhD) levels. The Embassy of the People's Republic of China in Malawi, reports that a total of 142 Malawians have benefited from Chinese government scholarships (2012). China Aid Data (2011) and the Chinese Embassy in Malawi also report that China has provided about 98 short study scholarships to Malawi government economic officials. As of March 2011, more than 500 Malawian officials and experts have visited China or attended short training programs. How the scholarships have contributed to Malawi's growth and development remains an area that needs to be studied in detail. This could also be an opportunity for Malawi to emphasize scholarships in areas that will match with Malawi's needs of diversifying its economy.

Lastly, unlike other studies, this study finds that China has contributed in addressing the structural problems in Malawi's higher education sector by building the Malawi University of Science and Technology. Construction of the buildings is now complete and the university has been established on $17^{\text {th }}$ December 2012 by an Act of Parliament. The university will offer courses in health and medical sciences, applied engineering and technology, earth and climate change science and also cancer research. Currently, the university has about 153 undergraduate students and 26 post- 


\begin{tabular}{|c|l}
\hline AFRICAN & Issue 4 \\
EAST-ASIAN & December 2014 \\
AFFAIRS & \\
\hline THE CHINA MONITOR \\
\hline
\end{tabular}

Table 10: Framework assessing impact of China on Malavi

\begin{tabular}{|c|c|c|c|}
\hline & & Direct & Indirect \\
\hline \multirow[t]{2}{*}{ Trade } & Complementary & $\begin{array}{l}\text { Inputs for Malawian industries } \\
\text { Cheap consumption of Chinese goods } \\
\text { Providing space for Malawi to improve its } \\
\text { competitive advantage } \\
\text { Zero tariffs on } 65 \text { per cent of certain exports } \\
\text { to China } \\
\text { Participation in China's international trade } \\
\text { fairs }\end{array}$ & $\begin{array}{l}\text { "Higher global prices for Sub } \\
\text { Saharan exports"(direct } \\
\text { quotation from Kaplinsky et } \\
\text { al, 2007) }\end{array}$ \\
\hline & Competitive & $\begin{array}{l}\text { Displacement of existing and potential local } \\
\text { producers by cheap Chinese products. } \\
\text { Unequal trade balance as trade is in favour } \\
\text { of China } \\
\text { Malawi's non-value added exports to China } \\
\text { versus China value added exports to Malami } \\
\text { Path dependence: neo-colonialist trade } \\
\text { pattems }\end{array}$ & $\begin{array}{l}\text { "Competition in extemal } \\
\text { markets-failing prices and } \\
\text { falling market shares" (direct } \\
\text { quotation from Kaplinsky at } \\
\text { al, 2007) }\end{array}$ \\
\hline \multirow[t]{3}{*}{$\begin{array}{l}\text { Investment/ } \\
\text { others }\end{array}$} & & Direct & Indirect \\
\hline & Complementary & $\begin{array}{l}\text { Chinese FDI Malawi sectors: } \\
\text { manufacturing, construction, agriculture } \\
\text { Low-cost infrastructure: roads, schools } \\
\text { blocks to mention a few } \\
\text { Agriculture expertise, technology and } \\
\text { investments } \\
\text { study scholarships (short term and long } \\
\text { term) and visits to China } \\
\text { Chinese doctors in Malawi's public health } \\
\text { Jobs for Malawians mostly the poor }\end{array}$ & $\begin{array}{l}\text { Future effects of Chinese } \\
\text { investments. } \\
\text { Environmental effects } \\
\text { Intergenerational effects of } \\
\text { Chinese investments }\end{array}$ \\
\hline & Competitive & $\begin{array}{l}\text { Displacement of existing and potential local } \\
\text { producers } \\
\text { Less spin-off to local economy than other } \\
\text { foreign contactors } \\
\text { Use of scarce resources-coal, timber } \\
\text { Environmental implications of resource } \\
\text { extraction and investments such as coal } \\
\text { thermal plant } \\
\text { Importation of Chinese labour }\end{array}$ & \\
\hline \multirow[t]{2}{*}{ Aid } & Complementary & $\begin{array}{l}\text { Grants and concessional finance } \\
\text { Technical assistance } \\
\text { Training } \\
\text { Infrastructural financing }\end{array}$ & \\
\hline & Competitive & $\begin{array}{l}\text { Long term implications of loans: } \\
\text { intergenerational debt bondage }\end{array}$ & \\
\hline
\end{tabular}

Source: $A$ uthors interpretation of Kaplinshy framework

(C) Centre for Chinese Studies, Stellenbosch University

All Rights Reserved. 
AFRICAN

EAST-ASIAN

AFFAIRS

graduate students.

\section{Conclusions and Recommendations}

At the individual level, Chinese investments have been a source of income for those employed in Chinese companies. At national level, in some instances Chinese investments have positively complemented the efforts of the Malawi government in terms of low cost infrastructure, agriculture, health and education. This reinforces the viewpoint raised in literature of China's positive role in the development of African countries. However there are negative effects in some instances, such as illustrated by the effect on the development of the leather industry in Malawi and on trade patterns.

Unbalanced trade patterns between China and Malawi are also of concern. Similar to other studies, results of this study show that trade benefits for Malawi are low as evident from the in-balance of trade between the two countries. This is an important issue as shown in the development implications in the areas of creating inequality of trade, import inflation and effects on Malawian society to mention a few. Another observation is the focus on primary products in Malawi's export basket compared to diversified exports on the Chinese side.

Reasons for low export penetration of Malawian products into the Chinese market are also highlighted, namely standards, demand and supply constraints. The Malawi government and relevant stakeholders could consider the following options to address the constraints:

- $\quad$ Firstly, address the limitations that reduce Malawi's benefits from Aid for Trade $^{2}$ such as the lack of alignment with national goals and local ownership (Said and Mcgrath et al, 2011). Aid for trade can also be channelled towards building trade infrastructure, local capacity in terms of information, skills and market access. In addition, it can be directed towards efforts to diversify the export basket of Malawi which is currently composed of agriculture products.

- $\quad$ Secondly, there should be increased efforts to link trade development skills 


\section{AFRICAN \\ EAST-ASIAN \\ AFFAIRS

and the education sector from primary through to university level. This will increase the skill base for government and related stakeholders. The education sector in Malawi should also shift towards courses that develop entrepreneurship potential and encourage innovative thinking. Instead of being trained to look for a job after studies emphasis should be on being trained to become social and business entrepreneurs. The Chinese government can provide scholarship in areas in which Malawi is still experiencing gaps. At the same time, standards regulating bodies should be trained on how they can improve standards of Malawian exports. The standard bodies should also be supported with up to date technology.

- Thirdly, Malawi should consider the prospects of interregional trade with other countries in the Southern Africa Development Community (SADC) region. Malawi can use its SADC membership to push for the removal of barriers that still affect growth of regional trade. Malawi can also use economic diplomacy tools (export promotions, investment agency, state visits and embassies) to boost its trade. Veenstra, Yahop and Bergeijn (2010) find a strong relationship between instruments of economic diplomacy and cross border trade, but gains are increased by choosing appropriate instruments for particular markets. Malawi can use the challenges it faces as landlocked country to lobby for preferential trade access to certain markets. However, Malawi has to ensure that its products and services are more diversified and of high quality. Malawi can also use the existing diplomatic relationship with China to negotiate for better terms of trade and more of diversified Malawian products and services in the Chinese market.

- $\quad$ Lastly, as pointed out in the introduction by Oyejide, Bankole and Adewuyi (2009) Malawi should look at how the availability of natural resources, external environment and investment institutions and policy choices have influenced its trade gains and losses with China so that the nation improves its trade potential and benefits. 
AFRICAN

EAST-ASIAN

AFFAIRS

The research also finds that there is no positive correlation between the amount of investments by China and the number of jobs created. In some years there are more investments but fewer jobs created. This suggests importation of Chinese labourers. A total of 13796 jobs were created from 2005 to 2012 which is a positive contribution considering a large number of those in the informal sector. The Malawi Government could sign an agreement with the Chinese embassy in Malawi outlining how many Malawians could be employed, the specific sectors and the terms of employment. This would secure more jobs for Malawians and ensure transference of skills over time. In addition, there should be a match between the technical school training and skills required for Chinese investments, so that importation of Chinese labour is reduced. Furthermore, there should be a transfer of higher end job managerial skills to qualified Malawians so that qualified Malawians are able to advance and receive promotions.

There is room for China to do more to boost Malawi's food security and encourage local agribusinesses. Initiatives for local processing of products are underway by the Malawi government but the challenge is poor packaging. China can come in to help in this area so that the products meet export standards. Future scholarship can look at the impact of China in each of the areas in details. China has also provided study scholarships to Malawians. However, future studies can also look at areas of study and how it has helped beneficiaries.

The overall conclusion is that China's role in Malawi's development is mixed with both gains and losses for Malawi. But there is room for Malawi to benefit more from the relationship. Malawi needs to have strategic and forward looking thinking so that it benefits more than it currently does. Malawi cannot copy what China has done to achieve economic growth and development. The Malawi government should develop its potential by identifying what Michael Porter (1998) calls "clusters of development" within the Malawian economy. The clusters will be the building blocks that could transform Malawi. They can be identified by conducting research within Malawi so that contextual issues are considered. 


\section{AFRICAN \\ EAST-ASIAN \\ AFFAIRS

The Chinese government also needs to deal with the Malawi government based on Malawi's level of development. This entails helping Malawi develop its potential in the four areas of co-operation. China needs to take responsibility for the role it plays in losses that accrue to Malawi. This will also help in shaping China's international image as it seeks to establish itself as a responsible global leader.

\section{Endnotes}

${ }^{1}$ The nine priority areas are agriculture and food security; energy and industrial development; mining and tourism; transport infrastructure and Nsanje World Inland Port; education, science and technology; public health, sanitation, Malaria, HIV and AIDS management; integrated rural development; Green belt irrigation and water development; child development, youth development and empowerment; climate change, natural resource and environment management (Government Malawi MDPC, 2012)

${ }^{2}$ The Organisation for Economic Cooperation and Development (OECD) defines aid for trade as a tool to strengthen the productive capacity of developing countries to deal with supply side constraints and also fill gaps in trade related infrastructure (OECD, 2013)

\section{Bibliography}

Adewuyi, A.O., Alarudeen, A., \& Kareem, O.I., 2010. Impact of China-Africa Trade Relations: The Case of Nigeria. Trade Policy Research and Training Programme. Ibadan. Nigeria and AERC.

African Development Bank. 2011. Malawi. In African Economic Outlook report [online]. Available: www.afdb.org/file admin/uploads [2012, September 19]

Amphiah, K., \& Naidu, S (eds). 2008. Crouching tiger, hidden dragon? Africa and China. Scottsvile, University of KwaZulu-Natal Press. 
AFRICAN

EAST-ASIAN

AFFAIRS

Ancharaz, V.D., \& Nowbutsing, B.M. 2010. Impact of China--Africa Investment Relations: An in-depth case study of Mauritius. Nairobi, AERC.

Anon. 2011. China-Malawi Relations in the Perspective of China-Africa Relations [online]. Available: mw.china-embassy.org/eng/sghdhzxxx/t885819.htm [2012, September 30].

Baah, A.Y., \& Jauch, H. 2009. Chinese investments in Africa: A labour perspective. African Labour Research Network.

Bazika, J.C.B. 2008. Economic Relations of China with the Republic of Congo. Nairobi, AERC.

Borovska, H. 2011. The China-Africa marriage. Copenhagen Business School.

Botolo,T. 2012. Malawi attends China-Africa Forum, economic growth tops agenda [NyasaTimes online, $18^{\text {th }}$ July]. Available : http:// www.nyasatimes.com/2012/07/18/malawi-attends-china-africa-forumeconomic-growth-tops-agenda/ [2012, September 21]

Chiang, F.Y. 2004. One-China Policy and Taiwan. Fordham International Law Journal, 28(1):1-87.

Chinese Embassy in Malawi, 2011. Religious leaders Workshop [online]. Available: http://mw.china-embassy.org/eng/sghdhzxxx/t825097.htm [2012, September 30]

Chinese Embassy in Malawi. 2010. Interview of H.E. Mr. Lin Songtian, Ambassador of the People's Republic of China on the Occasion of the 2nd Anniversary of the Establishment of Diplomatic Relations between the People's Republic of China and the Republic of Malawi [Online]. Available: http://mw.chinaembassy.org/eng/dsxx/dsjh/t652032.htm / [2012, September 30]

Chinguwo, P. 2009. Chinese Investments in Malawi. In: Baad, A.Y., \& Jaunch, H (eds), Chinese Investments in Africa: A Labour Perspective: Accra and Windhoek, 272-299. 
AFRICAN

EAST-ASIAN

AFFAIRS

Dulanya, Z. 2006. Geothermal Resources of Malawi - An Overview. Proceedings, Thirty-First Workshop on Geothermal Reservoir Engineering. Stanford University, Stanford, California, January 30-February 1, 2006 [Online]. Available: http://www.geothermal-energy.org/pdf/IGAstandard/SGW/2006/ dulanya.pdf. [2012, September 20].

Food and Agriculture Organisation (FAO). 2003. WTO Agreement on Agriculture: The Implementation Experience-Developing Country Case Studies-Malawi. Economic and Social Development Department, Rome. Available: http:// www.fao.org/docrep/005/y4632e/y4632e0n.htm [2012, September 25]

Giovannetti, G. \& Sanfilippo, M. 2009. Do Chinese Exports Crowd-out African Goodsandquest; An Econometric Analysis by Country and Sector. European Journal of Development Research, 21(4):506-530.

International Trade Centre. (n.d.). Trade statistics for international business development [online]. Available: http://www.trademap.org [2012, September 17]

Kaplinsky, R., Mccormick, D. \& Morris, M. 2007. The impact of China on subSaharan Africa. Institute of Development Studies, University of Sussex.

Karumbidza, J.B., 2007. Win-win economic cooperation: Can China save Zimbabwe's economy. African Perspectives on China in Africa. Nairobi, Pambazuka.

Khan, S.A., Baye, F.M. \& Tange, G.K. 2009. The Impact of China-Africa Trade Relations: Case Study of Cameroon. Nairobi, AERC.

Kiala, C. and Corkin, L. 2009. The Impact of China Investment Relations: The Case of Angola. Nairobi, AERC.

Malawi Investment and Trade Centre (MITC). 2012. Origin of Investors, Sectors, Investment and employment sectors. Malawi Investment and Trade Centre. 
AFRICAN

EAST-ASIAN

AFFAIRS

Malawi Ministry of Health. 2013. [Information on Chinese Doctors]

Mbekeani, K.K. 2004. Malawi: Studies on Past Industrial Trade Reforms Experience and Economic Implications. Botswana Institute for Development Policy Analysis \& Southern African Trade Research Network.

McNamee, T., Mills, G., Manoeli, S., Mulaudzi, M., Doran, S., \& Chen, E. 2012. Africa in their Words: A Study of Chinese Traders in South Africa, Lesotho, Botswana, Zambia and Angola. Brenthurst Foundation, Discussion Paper 2012/03

Ministry of Foreign Affairs of the People's Republic of China. 2010. China and Malawi. Available from: http://www.fmprc.gov.cn/mfa_eng/wjb_663304/ zzjg_663340/fzs_663828/gjlb_663832/Malawi_664084/. [Accessed: 2013, June 15].

Mshali, R. 2009. Mineral Resources of Malawi and Mining Potential. The Society of Malawi Journal, 62(2):27-35.

Ndulo, M. 2008. Chinese investments in Africa: a case study of Zambia, in Amphiah, K., \& Naidu, S. (eds). Crouching tiger, hidden dragon? Africa and China . Scottsvile, University of KwaZulu-Natal Press. 144.

Ngozo, C. 2012. Malawi's new law targeting Chinese traders in rural areas draws criticism [Guardian Newspaper Online, 9 August 2012]. Available from: www.guardian.co.uk [2012, September 19].

NyasaTimes, 2013. Banda meets China VP, Mudzi Trust gets MK8.5 BN boost [Nyasatimes Newspaper Online, 6 June 2013]. Available from: http:// www.nyasatimes.com/2013/06/06/malawi-pres-banda-meets-china-vp-mudzitrust-gets-mk8-5-bn-boost/ [2012, June 18].

Obiorah, N. 2007. Who's afraid of China in Africa? Towards an African civil society perspective on China-Africa relations. African perspectives on China in Afri- 
AFRICAN

EAST-ASIAN

AFFAIRS

THE CHINA MONITOR

ca.

Oyejide, T.A. Bankole, A.S., \& Adewuyi, A.O. 2009. China-Africa Trade: Insights from AERC scoping studies. European Journal of Development Research, 21(4).

Rutaihwa, J.L. and Mkwawa, A.R. 2011. Empirical Analysis of China-Africa Economic and Trade Cooperation for Good or Bad: A Case of Tanzania International. Journal of Academic Research in Business and Social Sciences, 1(3).

Saidi, M.D., \& Wolf,C. 2011. Recalibrating development co-operation: How can african countries benefit from Emerging partners? Working Paper No. 302, OECD Development Centre [online]. Available: http://www.oecd.org/dev/ emea/48450803.pdf. [2013, June 04].

Said, J., McGrath, J., Grant, C., \& Chapman, G. 2011. Evaluating Aid for Trade on the ground: Lessons from Malawi. Imani Development and South African Institute of International Affairs, Issue No. 21.

Schiere, R., Ndikumana, L., \&Walkenhorst, P. 2011. China and Africa: an Emerging Partnership for Development? African Development Bank Group. [online]. Available: http://www.afdb.org/fileadmin/uploads/afdb/Documents/ Publications/Anglaischina.pdf. Accessed: [2013, June 4].

Thomas Reuters Foundation. 2011. UK, Malawi expel each other's diplomats. Available: http://www.trust.org/item/20110427160500-j8xu2/?source=search [2012, September 21].

United Nations Development Programme (UNDP). 2011. Assessment of Development Results, evaluation of UNDP contribution in Malawi [online]. Available: $\quad$ http://erc.undp.org/evaluationadmin/downloaddocument.html? docid=4938 [2012, September 28].

United Nations Commodity trade (UNCOMTRADE). (n.d.). United Nations Commodity Trade Statistics Database. [online]. Available: http:// comtrade.un.org/db [2012, September 17]. 
AFRICAN

EAST-ASIAN

AFFAIRS

United Nations Commodity trade (UNCOMTRADE) in International Trade Centre. (n.d.). Trade by Commodity Statistics: Bilateral Trade between China and Malawi [online]. Available: http://www.intracen.org/itc/market-info-tools/ trade-statistics/ [2012, September 25].

United States Department of State. 2012. Background note: Malawi [online]. Available: http://www.state.gov/r/pa/ei/bgn/7231.htm\#foreign [2012, October 02]

Van Veenstra, V.M., Yakop, M., \& Van Bergeijk, P.A. 2010. Economic Diplomacy, the Level of Development and Trade. Netherlands Institute of International Relations Clingendael. Discussion Paper in Diplomacy 119, October 2010.

Villoria, N., Hertel, T., \& Nin-Pratt, A. 2009. China's growth and the agricultural exports of Southern Africa (No. 891). International Food Policy Research Institute (IFPRI).

World Bank. 2009. MALAWI Mineral Sector Review Source of Economic Growth and Development, July, 2009. Report No.50160-MW [Online]. Available: http://siteresources.worldbank.org/INTRANETENVIRONMENT/Resources/ MALAWIMINERALSECTORREVIEW.pdf. [2013, June 01].

Malawi Government Ministry of Development Planning and Cooperation. 2012. Malawi Growth and Development Strategy: 2012.

OECD. 2006. 'Aid for Trade': is it working? [Online]. Available: www.oecd.ws/dac/ aft/45581702.pdf. [2013, August 18]. 
AFRICAN

EAST-ASIAN

AFFAIRS

THE CHINA MONITOR

\section{Annex A: Areas of Chinese Investments and Total number of Companies}

\begin{tabular}{|c|c|c|c|c|c|c|c|c|}
\hline & 2005 & 2006 & 2007 & 2008 & 2009 & 2010 & $2011^{2}$ & 2012(up to July) \\
\hline Manufacturing ${ }^{b}$ & 21 & 23 & 43 & 19 & 4 & 5 & 9 & 6 \\
\hline $\begin{array}{l}\text { Trade(Import and } \\
\text { Distribution) }\end{array}$ & 1 & - & - & - & - & - & - & - \\
\hline Farming & 2 & - & - & - & - & & - & - \\
\hline Agriculture & - & - & - & - & & 2 & 2 & - \\
\hline $\begin{array}{l}\text { Tourism and } \\
\text { Hospitality }\end{array}$ & 1 & 4 & 3 & 4 & - & - & 2 & - \\
\hline Services $^{6}$ & 3 & 10 & 9 & 5 & 2 & 4 & - & 4 \\
\hline Infrastructure & - & - & - & - & - & - & - & 1 \\
\hline Agro processing & - & 1 & - & - & 1 & - & - & - \\
\hline Mining & - & - & - & - & - & 1 & - & - \\
\hline Total & 28 & 38 & 55 & 29 & 7 & 12 & 13 & 11 \\
\hline
\end{tabular}

Source: Authors calculations from data obtained from Malawi Inves tnent and Trade Centre.

${ }^{a}$ Few companies registered in 2011 and 2012 because of the political instability that Malawi experienced. Major donors left following poor governance concerns leading to the weakening of the Malawi currency, the kwacha and then the head of state died in April of 2012.

${ }^{\mathrm{b}}$ Manufacturing over the years has been in the following areas(shoes, textiles, feeds, sandals, cooking oil, soft drinks, disposable paper, plastic plates, furniture, tannery, food processing, detergents and blankets.

${ }^{\mathrm{c}}$ Also includes agriculture equipment.

${ }^{\mathrm{d}}$ Services have been in various areas: photographs, photo studio, restaurants, Chinese medicine, construction, advertising, designing, tyre retrade, and pharmaceutical. 
AFRICAN

EAST-ASIAN

AFFAIRS

\section{Annex B: Sector, Total Chinese investment and employment levels for the year}

\section{2 $^{\mathrm{e}}$}

\begin{tabular}{|c|c|c|c|c|c|}
\hline \multirow[t]{2}{*}{ Period } & \multirow[t]{2}{*}{ Sector } & \multicolumn{2}{|c|}{ Investment level (USS) } & \multicolumn{2}{|c|}{ Employment level } \\
\hline & & New(approv) & New(NA) & New(approv) & New(NA) \\
\hline $\operatorname{Jan} 2012$ & Services(consulting,designing) & $100,000.00$ & - & 100 & - \\
\hline April 2012 & Services(Tyre retrade) & - & $800,000.00$ & - & 20 \\
\hline \multirow[t]{2}{*}{ May/June 2012} & Manufacturing(furniture) & - & $300,000.00$ & - & 25 \\
\hline & Manufacturing(leather tannery) & $1,000,000.00$ & - & 90 & - \\
\hline \multirow[t]{3}{*}{$\begin{array}{l}\text { July/August } \\
2012\end{array}$} & $\begin{array}{l}\text { Manufacturing(Textiles and } \\
\text { Garments) }\end{array}$ & - & $150,000.00$ & - & 200 \\
\hline & $\begin{array}{l}\text { Manufacturing(plastic PVC } \\
\text { F.W) }\end{array}$ & - & $20,000,000.00$ & - & 14 \\
\hline & $\begin{array}{l}\text { Infrastructure(buildings,roads } \\
\text { and boreholes) }\end{array}$ & $200,000.00$ & - & 45 & - \\
\hline \multirow[t]{3}{*}{ September 2012} & $\begin{array}{l}\text { Services(hardware and general } \\
\text { shops) }\end{array}$ & $22,000,000.00$ & - & 30 & - \\
\hline & $\begin{array}{l}\text { Manufacturing(Plastic(PVC), } \\
\text { footwear }\end{array}$ & $20,000,000.00$ & - & 14 & - \\
\hline & $\begin{array}{l}\text { Manufacturing(textiles and } \\
\text { garments) }\end{array}$ & - & $150,000,00$ & - & 200 \\
\hline TOTALS & & $43,300,000.00$ & $21,250,000.00$ & 279 & 479 \\
\hline
\end{tabular}

Source: MITC, 2012

${ }^{\text {e }}$ From January to September 2012, US\$ 43,300,000.00 was approved under the column 'new approved' with a pledge of creating 279 jobs. US\$21,250,000.00 with a pledge of creating 479 jobs has not been approved. 